\title{
Occipital nerve block rapidly eliminates allodynia far from the site of headache: A case report
}

\author{
William B. Young \\ Thomas Jefferson University \\ Valentin Mateos \\ Hospital Central Asturias, Oviedo, Spain \\ Avi Ashkenazi \\ Thomas Jefferson University
}

Follow this and additional works at: https://jdc.jefferson.edu/neurologyfp

Part of the Neurology Commons

Let us know how access to this document benefits you

\section{Recommended Citation}

Young, William B.; Mateos, Valentin; and Ashkenazi, Avi, "Occipital nerve block rapidly eliminates allodynia far from the site of headache: A case report" (2004). Department of Neurology Faculty Papers. Paper 5.

https://jdc.jefferson.edu/neurologyfp/5

This Article is brought to you for free and open access by the Jefferson Digital Commons. The Jefferson Digital Commons is a service of Thomas Jefferson University's Center for Teaching and Learning (CTL). The Commons is a showcase for Jefferson books and journals, peer-reviewed scholarly publications, unique historical collections from the University archives, and teaching tools. The Jefferson Digital Commons allows researchers and interested readers anywhere in the world to learn about and keep up to date with Jefferson scholarship. This article has been accepted for inclusion in Department of Neurology Faculty Papers by an authorized administrator of the Jefferson Digital Commons. For more information, please contact: JeffersonDigitalCommons@jefferson.edu. 
Occipital Nerve Block Rapidly Eliminates Allodynia Far from the Site of Headache:

A Case Report

\author{
William B. Young, M.D. \\ Assistant Professor, Department of Neurology and \\ Director of Inpatient Program, Jefferson Headache Center \\ Thomas Jefferson University Hospital \\ Philadelphia, Pennsylvania
}

Valentín Mateos, M.D.

Department of Neurology

Hospital Central Asturias

33010, Oviedo (Spain)

Avi Ashkenazi, M.D.

Jefferson Headache Center

Department of Neurology

Thomas Jefferson University Hospital

Philadelphia, Pennsylvania 


\section{Background:}

Seventy to $80 \%$ of persons with migraine develop allodynia during the course of a severe attack (1). During a migraine attack, allodynia spreads topographically to extratrigeminal territory (1,2).Dynamic mechanical allodynia, otherwise known as brush allodynia (BA), is a subtype of allodynia that is easily tested.

Ashkenazi \& Young recently reported on the immediate benefits of greater occipital nerve (GON) block on brush allodynia and pain in migraine and in cluster headache $(3,4)$. In these studies, testing was performed at fixed sites in the trigeminal and cervical distributions. Allodynia in thoracic dermatomes was not studied.

\section{Case report:}

A 47-year-old woman with severe, left-sided menstrual migraine and chronic, left- more than right-sided posterior neck pain, was evaluated. Her last severe menstrual migraine lasted three days, ending seven days prior to presentation, at which time her neck pain was at its baseline. On examination, she had moderate cervical paraspinal tenderness and left-sided allodynia from C2 to T5, including her left arm. Brush allodynia was tested by stroking the subject's skin repetitively with a folded $2 \mathrm{X} 2$ inch gauze pad at $2 \mathrm{~Hz}$ until she experienced an unpleasant sensation or eight brushes were completed.

A left GON block and bilateral tender point injections at C2 and left C5 paraspinal and trapezius muscles were given. A total of 5cc of $2 \%$ lignocaine and $10 \mathrm{mg}$ of triamcinolone were used. One minute after achieving GON anesthesia the allodynia was reduced in intensity and all allodynia and neck pain had resolved after five minutes. 
Discussion:

In this report we show that GON block with paraspinal tender point injection can eliminate allodynia caudal to the site of injection. Previous reports of allodynia responding to GON block were consistent with an effect via convergent inputs to second order trigeminal nucleus caudalis neurons with expanded receptive fields. In order for such a monosynaptic process to be involved in this case, axons would need to enter the dorsal root entry zone at $\mathrm{T} 5$ and synapse with neurons near the cervicomedullary junction, a distance of approximately 0.3 meters, which is unlikely. We therefore offer an alternative explanation, and suggest that a more generalized process is involved. We propose that a diffuse antinoceptive process is initiated by GON/tender point anesthesia resulting in the turn-off of BA.

Diffuse noxious inhibitory controls (DNIC) occur when the response to a noxious stimulus is inhibited by a second, spatially remote, noxious stimulus (5). This phenomenon has been extensively studied in animal models of pain (6) and in man $(7,8)$. A possible explanation for our findings is, therefore, that the injections themselves initiated DNIC, independent of an anesthetic effect. The DNIC effect has been shown to start as early as one minute after the application of the noxious stimulus (8). This is in accordance with our observation in this patient. A saline injection could show that the technique was either due to DNIC or a placebo effect.

Further observations are needed to clarify whether it is the nociceptive element of injection or the anesthetic effect of GON/TP injection that turn off allodynia after GON block. 


\section{REFERENCES}

1. Burstein R, Yarnitsky D, Goor-Aryeh I, Ransil BJ, Bajwa ZH. An association between migraine and cutaneous allodynia. Ann Neurol 2000;47:614-24

2. Burstein R, Cutrer MF, Yarnitsky D. The development of cutaneous allodynia during a migraine attack clinical evidence for the sequential recruitment of spinal and supraspinal nociceptive neurons in migraine. Brain 2000;123 ( Pt 8):1703-9

3. Ashkenazi A, Young WB. Brush allodynia in cluster headache. Headache 2003;43:543. (Abstract)

4. Ashkenazi A, Young WB. The effects of occipital nerve block on brush allodynia and pain in migraine. Headache 2003;43:543. (Abstract)

5. Bouhassira D, Danziger N, Attal N, Guirimand F, Atta N. Comparison of the pain suppressive effects of clinical and experimental painful conditioning stimuli. Brain 2003;126:1068-78

6. Bouhassira D, Bing Z, Le Bars D. Studies of brain structures involved in diffuse noxious inhibitory controls in the rat: the rostral ventromedial medulla. J Physiol 1993;463:667-87

7. Watanabe S, Kakigi R, Hoshiyama M, Kitamura Y, Koyama S, Shimojo M. Effects of noxious cooling of the skin on pain perception in man. J Neurol Sci 1995;135:68-73

8. Witting N, Svensson P, Arendt-Nielsen L, Jensen TS. Differential effect of painful heterotopic stimulation on capsaicin-induced pain and allodynia. Brain Res 1998;801:206-10 